\title{
Entre a revolução e a institucionalização: a participação eleitoral do PC do B na história recente do Brasil
}

\section{Between revolution and institutionalization: the participation of PC do B in elections in Brazil's recent history \\ Jean Rodrigues Sales}

O interesse que pode suscitar a história recente ${ }^{1}$ do Partido Comunista do Brasil (PC do B) reside em pelo menos duas características que marcam a legenda no panorama da política brasileira. Em primeiro lugar, o partido é um dos mais antigos do país. Nascido em 1962, a partir de uma cisão no Partido Comunista Brasileiro (PCB), conta hoje com 46 anos de atividade política. Durante esse trajeto, passou por muitos percalços: sobreviveu à disputa ideológica com sua matriz, o PCB; ao período da última ditadura militar; à guerrilha do Ara-

Jean Rodrigues Sales é doutor em história social e professor adjunto da Unicentro, no Paraná (jeanrodrigues $5 @$ yahoo.com.br).

Texto recebido em 30 de maio e aprovado para publicação em 13 de agosto de 2008.

Nota do autor: Este texto é resultado de uma pesquisa de pós-doutorado realizada na USP com auxílio da Fapesp.

Estudos Históricos, Rio de Janeiro, vol. 21, n 42, julho-dezembro de 2008, p. 241-260. 
guaia, durante a qual dezenas de seus militantes foram assassinados; à concorrência de novas forças de esquerda surgidas no início dos anos 1980, em particular o Partido dos Trabalhadores (PT), e, principalmente, à crise do socialismo real que varreu do mapa a maioria dos partidos comunistas existentes no mundo. O PC do B, ao contrário, ampliou sua inserção política nos anos 1980 e 1990: conseguiu espaço no movimento sindical e estudantil e tem elegido vereadores, deputados e, mais recentemente, prefeitos e senadores. Além disso, em 2002, participou da coalizão que elegeu o presidente Luiz Inácio Lula da Silva.

Em segundo lugar, e considerando a trajetória acima apresentada, o partido foi relativamente pouco estudado e continua a exigir mais pesquisas acadêmicas a seu respeito. Na produção existente, os temas tratados dizem respeito principalmente à década de 1960 e à primeira metade dos anos 1970, que correspondem ao período de seu surgimento, estruturação política e envolvimento na guerrilha do Araguaia. Além disso, grande parte dos livros publicados é fruto de trabalhos jornalísticos, documentos do próprio partido ou de ex-militantes (Sales, 2007c).

Este artigo pretende contribuir para o entendimento da história recente do PC do B ao tratar de sua atuação no período que compreende a Nova República e a eleição presidencial de 2002. Esse período foi marcado por um deslocamento è esquerda na atuação do partido, o que aparecerá, no campo político, em suas alianças com o PT. O texto buscará o entendimento amplo das propostas e da atuação do partido até sua chegada ao governo federal juntamente com o PT, e destacará os pleitos eleitorais de que o grupo participou no período, os quais são tomados aqui como momentos importantes para a compreensão das mudanças nas propostas e na inserção do partido na história política brasileira.

\section{O governo Sarney: do apoio à crítica}

O PC do B participou ativamente da campanha das Diretas fá! em 1984. A derrota da Emenda Dante de Oliveira, que propunha a eleição direta para presidente da República, causou profundo desânimo nas forças que atuaram nas grandes mobilizações em favor do voto direto que marcaram o país naquele ano (Rodrigues, 2003; Delgado, 2007). Algumas dessas forças, como o PT, rechaçaram o resultado da votação da emenda e colocaram-se contra a participação na eleição indireta. Já o PC do B propunha que se mantivesse a mobilização popular, pois, mesmo com a derrota da emenda, o governo saíra enfraquecido. ${ }^{2} \mathrm{O}$ partido denunciava ainda aqueles que procuravam esvaziar o caráter popular da luta, passando às negociações de cúpula com vistas à sucessão no plenário da Câmara. ${ }^{3}$ 
Depois de muitas negociações entre os setores de oposição, e de uma crise na base governista, foram definidos os candidatos que concorreriam à eleição indireta para a presidência. De um lado, Tancredo Neves, do Partido do Movimento Democrático Brasileiro(PMDB), que recebeu apoio de setores dissidentes do Partido Democrático Social (PDS), mas não do PT, que se recusou a participar do Colégio Eleitoral; de outro lado, Paulo Maluf, apoiado pelo PDS. No dia 15 de janeiro de 1985, Tancredo Neves venceu a eleição. Pouco antes da posse, no entanto, foi submetido a uma cirurgia, vindo a falecer no dia 21 de abril. Assumiu a presidência o seu vice, José Sarney, dando início ao período da Nova República.

Logo após a vitória de Tancredo, o PC do B fez uma análise positiva do resultado. Em primeiro lugar, destacou que a eleição, ainda que indireta, colocara fim ao regime militar, o que não teria sido possível sem a mobilização popular. Naquela situação, a tática partidária deveria ser uma política ampla, junto com as mais variadas correntes de opinião, voltada para a mobilização de massa "no sentido de garantir as mudanças reclamadas pelo povo, vencendo as resistências dos setores conservadores do governo". 4

Com a chegada de Sarney à presidência, o partido continuou a política de frente ampla para defender o aprofundamento das liberdades democráticas. Nesse sentido, desde o princípio apoiou o governo, na medida em que este representaria avanços no processo de redemocratização. Por exemplo, afirmava o PC do $\mathrm{B}$, o novo presidente apoiava a legalização de todos os partidos, inclusive os comunistas; admitia o direito de greve aos trabalhadores; respeitava o Congresso nacional e os direitos humanos e, por fim, estava engajado na convocação da Constituinte. ${ }^{5}$ Era portanto necessário reconhecer aspectos positivos e negativos em sua atuação. Uma oposição sistemática estava descartada, uma vez que isso facilitaria o jogo da direita que ainda ansiava pela volta à ditadura. ${ }^{6}$

Em 1985, o PC do B conseguiu sua legalização junto ao Tribunal Superior Eleitoral (TSE). Com a legalidade em mãos, participou da campanha eleitoral de 1986, pela primeira vez com seus candidatos inscritos na própria legenda. ${ }^{7}$ A campanha e o momento político estavam marcados pelo debate em torno da Constituinte, tema a que o partido dedicou toda a sua atenção (Amazonas, 1985). Para o PC do B, somente a nova Constituição poria fim a todo o aparato do regime militar e possibilitaria à população a conquista de direitos. Entretanto, caberia à oposição se unir contra as forças conservadoras que se posicionariam hostilmente à conquista desses direitos. Nesse caminho, o partido manteve sua proposta de ampla frente política até o final da Constituinte. $\mathrm{Na}$ segunda metade dos anos 1980, porém, o grupo reorientaria sua atuação na política nacional. No início de 1987, abandonou o apoio crítico ao governo Sarney, passando à oposição. Em linhas gerais, o PC do B avaliava que o governo passara completamente para o campo conservador, deixando assim de representar qualquer aspiração popular. ${ }^{8}$ 


\section{$O 7^{\circ}$ Congresso: mudança de rumo e aliança com o PT}

O PC do B realizou o seu $7^{\circ}$ Congresso em maio de 1988. Entre os temas tratados na ocasião, vamos destacar aqui a reorientação da atuação política do partido, que sofreria uma guinada à esquerda, evidenciada na reafirmação de sua postura de crítica ao governo Sarney e na aproximação com o PT (PC do B, 1989).

Para compreender as alianças do PC do B com o PT, iniciadas na segunda metade dos anos 1980, é necessário, primeiramente, lembrar que o partido de João Amazonas sempre fora um crítico tenaz do partido de Lula. Os motivos das críticas dirigidas ao PT podem ser entendidos, de um lado, pela própria concorrência dos dois agrupamentos dentro dos segmentos da esquerda brasileira; de outro lado, na lógica da política de unidade até então defendida pelo PC do B, o PT era criticado por ter rompido a união nacional na luta contra a ditadura, uma vez que não se unira ao PMDB, e por não ter apoiado logo depois a Nova República (Sales, 2007b).

No momento da realização do congresso, mudanças na conjuntura política levaram o PC do B a rever seu posicionamento frente ao PT. A principal mudança se deu a partir do rompimento com o governo Sarney e da busca de composição de um amplo movimento de unidade das forças "progressistas e democráticas" (PC do B, 1989: 31). Foi isso que abriu caminho para a aproximação com o PT. Essa nova relação, no entanto, não significava uma adesão ao projeto petista. Para o PC do B, o PT continuava a representar as idéias da social-democracia no Brasil, o que significa dizer que dividia o movimento operário e criava organizações de massas a ele subordinadas, como a Central Única dos Trabalhadores (Ibidem: 41). Apesar das críticas, o PC do B afirmava que seria um "erro tático atacar o PT em bloco", já que nele "militam homens e mulheres progressistas, contingentes proletários dispostos a defender seus interesses e que se mostram subjetivamente a favor do socialismo" (Ibidem: 41-42). A coligação com o PT era enquadrada dentro da proposta do PC do B de frente ampla, a fim de dar consistência a um movimento capaz de derrotar "os inimigos dos trabalhadores e da nossa pátria e garantir um futuro melhor para o Brasil" (Ibidem: 43).

$\mathrm{O} 7^{\circ}$ Congresso do $\mathrm{PC}$ do $\mathrm{B}$ definiu a tática partidária a ser adotada nos anos seguintes. O centro se voltava para a sucessão presidencial de 1989, e o partido apontou como objetivo principal procurar "influir no surgimento de um concorrente democrático e progressista, capaz de reunir o apoio da esquerda e também do centro" (Ibidem: 30). Para tanto, a bandeira empunhada pelo candidato à presidência deveria ser de unidade das forças de centro-esquerda. Caso não fosse viabilizada uma candidatura com tais características, $\mathrm{o}$ PC do B preten- 
dia indicar um candidato próprio no primeiro turno com vistas a difundir as idéias socialistas.

\section{As coligações políticas e as eleições nos anos 1980}

O ano de 1988 marcou um momento importante na história do PC do B. Nesse momento o partido passou a participar periodicamente de coligações eleitorais com outros partidos de esquerda, especialmente com o PT, mas também, em alguns casos, dadas as particularidades locais, com partidos de centro-direita. Essa política ampla de alianças talvez ajude a compreender o relativo crescimento do número de votos recebidos pelo partido no decorrer dos anos $1980 \mathrm{e}$ 1990, quando outros partidos comunistas, no Brasil e no mundo, seguiram tendência inversa. A aliança com o PT, maior partido da esquerda brasileira, certamente contribuiu para dar maior visibilidade às propostas dos comunistas e proporcionar uma expansão de seu espaço eleitoral.

As eleições municipais de 1988 podem ser tomadas como um marco da política de alianças do PC do B. Nesse ano, o partido integrou a coligação Partidos do Povo na eleição municipal de São Paulo. A frente era composta ainda por PT e PCB e teve como candidata majoritária Luiza Erundina, do PT. No lançamento da coligação, o PC do B afirmava que unidade eleitoral "não enterra divergências, mas também não as semeia". O mais importante era o fato de estarem unidos "os que lutaram e lutam pelos direitos dos trabalhadores na Constituinte", selando, assim, a "vontade das ruas, do que existe de mais avançado nas fábricas, nas escolas e nos dormitórios operários da grande capital" (Rebelo, 1988; Carvalho, 1988a).

A análise feita pelo PC do B do resultado das eleições municipais de 1988 foi bastante positiva e destacava pelo menos dois pontos importantes. Em primeiro lugar, em termos efetivos, o partido passou de 6 para 15 vereadores nas capitais e de 22 para 60 no conjunto do país. Destes, 16 foram eleitos na Bahia e 2 em São Paulo (Carvalho, 1988b: 2). Além disso, avaliava-se que nos principais centros políticos e econômicos do país teriam vencido candidatos identificados com "propostas democráticas e progressistas, vinculados ao povo trabalhador, abertamente contrários às elites, em composições em que se uniram forças políticas progressistas e de esquerda". ${ }^{9} \mathrm{O}$ segundo ponto destacado era que as eleições de 1988, sobretudo com a vitória em São Paulo (Rebelo, 1989), abria a perspectiva de formação de uma nova frente política visando à sucessão presidencial de 1989. Nesse caminho, o PC do B propunha que se formasse uma coligação das forças democráticas já no primeiro turno das eleições. ${ }^{10}$ 
Em abril de 1989, o partido destacava em seu jornal a reunião realizada em Brasília no dia 29 de março, na qual os presidentes nacionais do PT, do Partido Socialista Brasileiro (PSB), do Partido Verde (PV) e do PC do B decidiram participar unidos da campanha sucessória. $\mathrm{O}$ lançamento da frente de esquerda, afirmava o PC do B, apontava para uma perspectiva de vitória. ${ }^{11}$ No dia 13 de maio foi oficializada a Frente Brasil Popular com um comício realizado em São Bernardo do Campo, que deu início à campanha eleitoral. ${ }^{12} \mathrm{O} \mathrm{PC}$ do $\mathrm{B}$ apresentou 20 pontos amplos para o programa da Frente, com destaque para a defesa da soberania nacional e dos trabalhadores. ${ }^{13}$

Nas vésperas das eleições, o PC do B avaliava que a vitória estava ao alcance das mãos e que havia condições concretas para que o candidato da Frente Brasil Popular, Luiz Inácio Lula da Silva, fosse para o segundo turno e ganhasse as eleições. ${ }^{14} \mathrm{O}$ resultado da votação no primeiro turno pareceu comprovar o otimismo do partido, que afirmou ter sido virada uma página na história do país. Era, porém, necessário se preparar para a grande batalha do segundo turno, quando a direita poderia recorrer a "todos os meios para levar Collor ao Planalto". ${ }^{15}$ De fato, nos últimos dias da campanha eleitoral, o candidato Fernando Collor recorreu a falsas denúncias pessoais contra Lula, o que, com a ajuda de parte da mídia, contribuiu para derrotar a Frente Brasil Popular nas urnas (Pilagallo, 2006: 42-45).

A derrota de Lula causou um grande abalo nas forças de esquerda no país. Além do sentimento de que se havia perdido uma chance real de chegar ao poder, havia a constatação da implantação de um projeto afinado com as diretrizes neoliberais, que levaria o país, mas principalmente a parte mais pobre da população, a uma década de grandes dificuldades. A primeira medida do novo governo, que causou surpresa mundial, foi o "confisco" das aplicações nas cadernetas de poupança feita pela equipe econômica (Pilagallo, 2006). O PC do B, apesar da derrota, procurou ressaltar a importância histórica da eleição de 1989:

O Brasil-90 não é o mesmo da ditadura militar nem da finada Nova República. Não é tampouco o Brasil da gang de Collor, um país de simulacros e fantasias. O Brasil que emerge da campanha sucessória é o da luta pela democracia e a independência, bandeiras que continuam nas mãos firmes da oposição popular emergente. ${ }^{16}$

Com essa perspectiva, no início dos anos 1990, o PC do B propôs que se continuasse a união de esquerda nas eleições para governador que aconteceriam naquele ano. ${ }^{17}$ Avaliou ainda que a situação não era favorável às forças populares e decidiu pregar o voto nos candidatos que fossem adversários de Collor, mesmo que estivessem fora do campo das esquerdas. 


\section{Os anos 1990 e a luta contra o neoliberalismo}

Tendo como preocupação central a defesa do país diante dos ataques do governo Collor, o partido propôs a formação de um amplo movimento antiimperialista e democrático que reunisse as massas populares, a intelectualidade progressista, setores militares, em suma, "todos que amam a pátria e não querem transformar-se em meros agregados, em vassalos da superpotência norte-americana" (PC do B, 1992: 32). Com essa proposta, o PC do B iria se dedicar, no início dos anos 1990, ao movimento Fora Collor, às eleições de 1992 e, de uma forma mais ampla, ao combate ao avanço do projeto neoliberal no Brasil.

Nesse caminho, nas eleições municipais de 1992, o PC do B continuou a sua política de amplas alianças com as correntes de centro-esquerda, englobando os tradicionais aliados PT, Partido Democrático Trabalhista (PDT) e PSB, e ainda PMDB e Partido da Social Democracia Brasileira (PSDB) em alguns estados. Na campanha, o discurso do partido procurava atrelar o amplo movimento pelo impeachment de Collor a um pretenso movimento da sociedade contra o projeto neoliberal. ${ }^{18}$

O resultado da eleição pode ser visto como uma vitória política do partido, se considerarmos que, mesmo diante da grande campanha anticomunista que vigorava no período, a legenda elegeu 53 vereadores, 13 nas capitais e 40 no interior, com destaque para os estados da Bahia e São Paulo, onde foram eleitos 8 vereadores em cada. 19

Com o afastamento de Collor, assumiu seu vice, Itamar Franco. Tendo participado ativamente da campanha pelo impeachment, o PC do B defendeu a posse e o governo de Itamar. Na avaliação do partido, o novo presidente assumira em condições difíceis e era necessário apóia-lo visando à defesa da nação. ${ }^{20} \mathrm{O} \mathrm{PC}$ do B enfatizava o caráter nacionalista do governo, que se teria predisposto a reavaliar as privatizações em curso e a investir contra o monopólio da indústria farmacêutica, e acenava com a adoção de medidas de cunho social. Por tudo isso, representava "uma ruptura com o projeto neoliberal do governo anterior e por isso mesmo atraía a ira das elites conservadoras e do imperialismo". Assim, "mais do que nunca está em jogo a governabilidade de Itamar". O apoio ao governo Itamar perdurou até que divergências políticas em torno das próximas eleições presidenciais e da política econômica levaram o PC do B à oposição (Silva, 2004).

Em 1993, foi a vez da participação na campanha do plebiscito que decidiria a forma e o sistema de governo no Brasil. Coerente com a sua participação na Constituinte, o PC do B apoiou a proposta de uma República parlamentarista no Brasil. O partido considerava que o presidencialismo, em mais de cem anos, revelara ser um sistema fechado e autoritário, responsável em grande parte pelo atraso político e cultural do país. O parlamentarismo, por sua vez, seria um siste- 
ma mais flexível e menos personalista, capaz de propiciar maior participação da população na vida política nacional. ${ }^{21}$ Para tanto, na proposta do PC do B estavam incluídas "a co-responsabilidade entre o Executivo e o Legislativo, a eleição por voto direto, secreto e universal do presidente da República e dos membros do Congresso Nacional", e também "a recusa do sistema de voto distrital e a manutenção do voto proporcional" (Silva, 2004). Realizada a consulta, ganhou com ampla maioria a República presidencialista.

No início de 1994, o PC do B já direcionava suas expectativas para a sucessão presidencial. No dia 30 de janeiro, lançou uma nota conclamando a necessidade de formação de nova frente das forças nacionais e democráticas visando à eleição. Inicialmente, a proposta era fazer uma reunião com os pré-candidatos progressistas e os partidos de esquerda para discutir um nome capaz de aglutinar tais forças e enfrentar as elites. ${ }^{22} \mathrm{~A}$ coligação que se formou para sustentar a candidatura de Lula foi composta por PT, PC do B, PSB, PCB, Partido Socialista dos Trabalhadores Unificado (PSTU) e Partido Popular Socialista (PPS). Já a candidatura de Fernando Henrique Cardoso foi apoiada por PSDB, Partido da Frente Liberal (PFL) e Partido Trabalhista Brasileiro (PTB). O PC do B se empenhou na campanha e não poupou críticas ao candidato do PSDB, que já era alvo do partido desde o momento em que assumira a pasta da Fazenda do governo de Itamar Franco, quando foi apontado como "o novo porta-voz do projeto neoliberal no Brasil, podendo se transformar no candidato 'viável' das elites dominantes para 94 ". 23

As duas principais candidaturas, de Fernando Henrique e de Lula, representavam, segundo o PC do B, dois caminhos opostos para os destinos do país. A primeira seria a expressão de interesses externos, baseados nos ditames do neoliberalismo. A segunda, a opção por uma via de desenvolvimento independente empenhada em atender os interesses populares (Ruy, 1994: 6). Para a realização de seus projetos, Fernando Henrique estaria articulando uma grande aliança com proprietários, "desde a Fiesp aos coronéis renovados do Nordeste”. Já a Frente Brasil Popular uniria assalariados da cidade e do campo, intelectuais, profissionais liberais e setores empresariais "cuja situação os coloca em contradição com o grande capital brasileiro e estrangeiro, e que pretendem usar o mercado interno como uma plataforma para alcançar o mercado mundial" (Ibidem: 8).

Inicialmente, os números das pesquisas eleitorais apontavam ampla maioria em favor da candidatura Lula. Entretanto, o panorama mudou a partir do lançamento do Plano Real pelo ministro da Fazenda Fernando Henrique Cardoso, principalmente a partir de julho, quando houve o lançamento da nova moeda, o real, e uma diminuição dos índices inflacionários. Aos poucos, o candidato da Frente Brasil Popular foi ultrapassado, e Fernando Henrique foi eleito no primeiro turno da eleição com cerca $54 \%$ dos votos. 
O PC do B avaliou que a vitória de FHC resultara da ação das forças conservadores do país, que souberam aproveitar o sucesso inicial do Plano Real, na mesma medida em que Lula não soubera enfrentar o consenso criado em torno do plano econômico. Sobre o novo governo, afirmava que, pelos compromissos assumidos na campanha, tentaria aplicar medidas "antinacionais e antidemocráticas", como "a revisão da Constituição, a 'reestruturação' do Estado e igualmente a privatização de empresas estatais de importância fundamental". ${ }^{24}$ A eleição teria demonstrado também avanços do campo democrático, como a conquista do governo de Pernambuco por Miguel Arraes e do Mato Grosso por Dante de Oliveira. Além disso, o PT aumentou sua bancada de deputados, passando de 36 para 49, e elegeu 4 novos senadores. O PC do B, por sua vez, duplicou sua bancada federal, passando de 5 para 10 deputados. ${ }^{25}$

Com o anúncio dos planos do novo governo, o PC do B passou imediatamente a criticá-lo. Na avaliação do partido, as medidas apresentadas por Fernando Henrique Cardoso eram idênticas às que haviam sido adotadas em outros países da América Latina, cuja lógica principal era o aprofundamento da dependência em relação ao imperialismo, e que tiveram no caso mexicano seu maior exemplo. No Brasil, a especificidade seria a de o governo não assumir sua feição neoliberal e tentar apresentar-se como representante da social-democracia. Porém, as medidas visando ao desmonte das estruturas estatais, econômicas e sociais denunciariam a "total submissão ao projeto do neoliberalismo" (Rabelo, 1995: 17).

Passados alguns meses do início da nova administração, o PC do B constatava que se vivia um grave momento na situação política nacional. O governo estaria empreendendo uma verdadeira reforma constitucional sem que para tanto tivesse sido eleita uma Assembléia Constituinte. O partido apontava como maiores exemplos desse processo o fim dos monopólios estatais, o ataque aos direitos trabalhistas a fim de adaptá-los à globalização da economia, as modificações na legislação eleitoral com as propostas da cláusula de barreira e do voto distrital misto, a proibição das coligações nas eleições proporcionais, todas medidas que, se aprovadas, dariam feição autoritária ao sistema político brasileiro. ${ }^{26} \mathrm{Co}-$ roando o caráter antidemocrático desse processo, viria a proposta de reeleição do presidente da República, "carro-chefe da reforma política pretendida pelos defensores do neoliberalismo", a qual visaria, no fundo, a "adequar o Estado às necessidades do projeto neoliberal" (Arantes, 1997: 42).

No decorrer do governo de Fernando Henrique Cardoso o PC do B manteve as críticas ao seu projeto político e econômico. A tônica era a da vinculação das medidas adotadas no Brasil com o avanço do neoliberalismo em escala mundial, particularmente na América Latina. Nesse caminho, já no primeiro semestre de 1997 o partido começou a traçar os planos para a sucessão presidencial do ano seguinte. $O$ primeiro passo foi dado ainda em junho em uma reunião das 
bancadas de oposição no Congresso. No encontro, decidiu-se pela criação de um grupo de trabalho para elaborar um documento-base a ser submetido a um encontro nacional de partidos de oposição visando ao lançamento de uma candidatura unitária. ${ }^{27}$

Dando continuidade à política adotada nas eleições anteriores, o PC do B afirmava a necessidade de união das esquerdas como condição indispensável para que as oposições pudessem ganhar a eleição. ${ }^{28}$ Para o partido, o objetivo principal na eleição era derrotar o projeto neoliberal implantado por Fernando Henrique Cardoso, e o programa oposicionista deveria refletir tal posição. A base das propostas deveria, assim, estar no rompimento do equilíbrio político dominante, no fortalecimento do Estado Nacional e na adoção de um novo modelo de desenvolvimento baseado nas necessidades do povo e do país. A capacidade de implantação desse projeto, afirmava o PC do B, passava por uma decisão política, e não técnica: "as soluções técnicas existem, mas sua aplicação depende da capacidade de unir amplas forças sociais e apoio popular - capacidade que é, antes de tudo, política" (Rabelo, 1998: 8).

A coligação dos partidos de oposição formou-se em torno dos candidatos Luiz Inácio Lula da Silva, do PT, e Leonel Brizola, do PDT. O ato inaugural ocorreu na sede do PT paulista no dia 12 de maio de 1998, e dele participaram ainda o PC do B e o PSB. ${ }^{29} \mathrm{~A}$ campanha eleitoral transcorreu com a oposição criticando a vulnerabilidade às crises externas a que o Plano Real havia sujeitado o país, e com Fernando Henrique Cardoso enfatizando a necessidade da continuidade da moeda que havia conseguido praticamente acabar com a inflação. Nas palavras de um membro do PC do B, Fernando Henrique "continua no caminho aberto por Fernando Collor, de atualizar a velha opção pelo atraso e pela dependência”. Do outro lado, Lula e a União do Povo - Muda Brasil eram herdeiros da tradição que defendia "um projeto de desenvolvimento baseado no trabalho dos brasileiros" (Ruy, 1998: 9). Na abertura das urnas, percebeu-se que o discurso da estabilidade e da continuidade saíra vencedor, e o candidato do PSDB foi reeleito no primeiro turno com cerca de $53 \%$ dos votos.

$\mathrm{Na}$ apreciação do presidente do PC do B, a eleição teria sido "atípica", na medida em que havia se desenrolado em condições internas e externas adversas. Nesse sentido, a vitória de Fernando Henrique Cardoso deveria ser "relativizada", pois mesmo tendo utilizado a máquina do Estado, e contado com o apoio da grande imprensa durante a campanha, sua votação sofrera pequena diminuição em relação ao pleito anterior. Ao mesmo tempo, o dirigente destacava o importante papel de Lula, que se consagrou então como inconteste liderança nacional. ${ }^{30}$

O PC do B elegeu 10 deputados estaduais e 7 federais. Houve ainda um aumento da votação absoluta do partido, mas não o suficiente para aumentar a 
votação relativa, que se manteve em $1,25 \%$ do eleitorado nacional. ${ }^{31}$ Mesmo com a diminuição da bancada federal, de 10 para 7 deputados, o partido avaliou positivamente sua participação na campanha, a qual teria servido para denunciar o projeto político de Fernando Henrique Cardoso. ${ }^{32}$ Sobre o novo governo, o PC do B avaliou que seguiria a mesma política adotada durante o primeiro mandato e que o partido deveria procurar unir todas as forças sociais para combatê-la. ${ }^{33}$

\section{As eleições municipais de 2000 e a antecipação do debate sucessório}

Em julho de 1999, o PC do B começou a se mobilizar para as eleições municipais que ocorreriam no ano seguinte. Inicialmente, o objetivo era chamar a atenção para a necessidade de aumentar o efetivo parlamentar do partido, ao mesmo tempo que continuavam as críticas ao governo de Fernando Henrique Cardoso e a busca de alianças com os setores de esquerda. ${ }^{34}$ Como em outras ocasiões, e de acordo com sua estratégia política, o partido procurou fazer alianças com partidos de oposição, particularmente com o PT. A novidade desse pleito para a trajetória do $\mathrm{PC}$ do $\mathrm{B}$ foi que o partido investiu também em candidaturas majoritárias, lançando 26 candidatos a prefeito e 46 a vice-prefeito, inclusive em algumas capitais. ${ }^{35}$

No primeiro turno da eleição, o PC do B experimentou expressivo crescimento. Elegeu 7 vice-prefeitos, incluindo o de Aracaju, capital de Sergipe. Vereadores, foram eleitos 150, 55 a mais do que no pleito anterior. Destes, 18 assumiram seus cargos em capitais de estado. Em Fortaleza e Olinda os candidatos a prefeito do partido foram para o segundo turno, assim como o candidato a vice-prefeito em Recife (Rabelo, 2000: 3). No segundo turno, os resultados mais importantes aconteceram em Pernambuco, onde foram eleitos o vice-prefeito de Recife, Luciano Siqueira, e a prefeita de Olinda, Luciana Santos. No caso de Olinda, o PC do B deu amplo destaque à vitória de sua candidata, uma vez que foi a primeira vez que o partido ocupou um cargo majoritário em uma cidade de grande importância histórica para o país. ${ }^{36}$

Além do aumento relativo obtido pelo partido nas eleições de 2000, o PC do B participou de coligações vitoriosas em 240 municípios e avaliou o resultado geral do pleito como extremamente positivo para as forças de oposição, abrindo perspectivas para a sucessão presidencial de 2002. O partido baseava sua análise nos números obtidos pelos partidos de esquerda: no conjunto de 57 cidades com mais de 200 mil habitantes, a oposição elegeu 27 prefeitos, e o PT conseguiu eleger 187 no total dos municípios brasileiros, englobando $20 \%$ da população. Além disso, a vitória da oposição em São Paulo, a maior cidade do país, com a eleição 
para a prefeitura de Marta Suplicy, do PT, indicava, segundo o PC do B, uma mudança no quadro político nacional. ${ }^{37}$

Dessa forma, para o partido, diante do resultado eleitoral, surgia uma nova correlação de forças políticas "favoráveis à oposição e aos partidos de esquerda, passando assim a condicionar o curso do processo político que culminará na eleição presidencial de 2002" (Rabelo, 2000/2001: 14). Diante do novo quadro, o maior desafio para as lideranças da oposição seria se concentrar na tarefa de "redefinir e recompor uma ampla frente política capaz de garantir as condições para derrotar o governo neoliberal" (Ibidem: 15).

\section{Os comunistas no poder: a eleição de 2002 e a chegada ao governo federal}

Em agosto de 2001 o PC do B abriu o debate sobre a sucessão presidencial do ano seguinte. Antes de qualquer contato com outros partidos, sua comissão política lançou uma nota em que colocava em pauta os pontos que julgava fundamentais para a elaboração de um projeto político capaz de se contrapor ao neoliberalismo e ao governo Fernando Henrique Cardoso.

Para o PC do B, uma proposta alternativa para o país deveria contemplar críticas às articulações em torno da Área de Livre Comércio das Américas (Alca); a denúncia dos acordos com o FMI e com a Organização Mundial do Comércio; uma auditoria soberana nas dívidas internas e externas; a suspensão e revisão das privatizações nos setores estratégicos; a retomada do desenvolvimento, a diminuição da jornada de trabalho, a melhoria das condições de vida dos trabalhadores e a reforma agrária; o incentivo à pesquisa científica e tecnológica e ao ensino público, e a convocação de uma Assembléia Constituinte que expressasse um novo pacto político e social (Rabelo, 2001a: 7-9).

O partido procurava articular a sucessão presidencial com a conjuntura política nacional, a qual estaria marcada pelo esgotamento da aplicação da política neoliberal. Para o PC do B, o "conto mirabolante" de que a abertura e o fluxo de capital privado estrangeiro bastariam para elevar a produtividade, "propiciar a diversidade da atividade econômica e produzir os investimentos suficientes para a edificação da infra-estrutura e dos serviços públicos, sem a intervenção do Estado", revelara-se uma fantasia, e o país mergulhara em profunda crise (Rabelo, 2001/2002: 6). Ao mesmo tempo que o modelo neoliberal demonstrava o seu esgotamento, começavam a ressurgir também amplos movimentos contestatórios da nova ordem mundial, como exemplificava o Fórum Social Mundial, realizado em Porto Alegre em janeiro de 2001. Na avaliação do PC do B, a realização do Fórum e a crise do neoliberalismo colocavam em pauta a necessidade de uma ampla articulação política para derrotar o candidato do PSDB (Rabelo, 2001b). 
O apoio do PC do B à candidatura de Luiz Inácio Lula da Silva começou a se delinear em abril de 2002, quando o candidato petista foi até a sede nacional do partido convidar oficialmente a organização a integrar a frente política. Naquele momento, o PC do B já deu indícios de que continuaria no caminho que seguia desde a eleição de 1989, quando foi feita a primeira aliança em apoio a Lula. Afirmou ainda que o mais importante era que houvesse um programa que se diferenciasse claramente do projeto do PSDB e que se buscasse a ampliação dos aliados para que se tornasse viável a vitória do candidato das oposições. ${ }^{38}$

$\mathrm{Na}$ apresentação de suas propostas para a elaboração do programa da Frente Lula Presidente, formada por PT, PC do B, Partido Liberal (PL), Partido da Mobilização Nacional (PMN) e PCB, o partido insistiu que estavam em jogo na eleição de 2002 dois caminhos distintos para o Brasil. De um lado, aquele que procurava impor à nação mais um projeto conservador, que buscava resolver a questão da vulnerabilidade externa apenas para perpetuar o sistema de dependência oriundo da política neoliberal implantada desde os anos 1990. De outro lado, um projeto alternativo de caráter nacional, democrático, popular e progressista, que visava a construir um caminho de desenvolvimento autônomo para o país. A execução desse programa passaria, primeiramente, por uma decisão política de reunir as forças necessárias para fazer frente ao neoliberalismo. ${ }^{39}$ Sobre a questão econômica, item fundamental do programa, o PC do B afirmava que:

a) o novo modelo econômico baseia-se na concepção de que a economia brasileira é uma economia de natureza continental, com uma vocação natural à diversidade e à auto-suficiência; b) a política econômica deve ter como prioridade aumentar o nível e a qualidade de vida material e cultural do povo, dando mais segurança a seu futuro; c) o Estado deve assumir papel preponderante no investimento em setores estratégicos para o desenvolvimento, dirigir e planejar o esforço nacional, cuidando para que os resultados do progresso tenham divisão mais equânime, premiando o esforço e a inventividade e dando primazia à valorização do trabalho; d) o financiamento do desenvolvimento deve se basear na poupança nacional e ampliação do mercado interno, sendo o capital externo complementar e secundário. ${ }^{40}$

A Frente Lula Presidente teve como adversário o candidato do PSDB, José Serra, apoiado pelo PMDB. A candidatura de Serra sofreu com a perda de apoio do PFL, que após poucos meses de campanha rompeu com o PSDB. Além disso, Serra se viu na condição de defender um legado de oito anos de governo de Fernando Henrique Cardoso. A fraqueza de sua campanha apareceu no resulta- 
do do primeiro turno, quando Lula quase foi eleito ao receber $46,47 \%$ dos votos, enquanto Serra ficou com $23,19 \%$. No segundo turno, a vitória de Lula se confirmou, tendo ele recebido $61,27 \%$ dos votos, contra 38,73 de Serra.

$\mathrm{O} P C$ do B experimentou um relativo crescimento nessa eleição. O partido lançou 208 candidatos, sendo 127 às Assembléias Legislativas, 52 à Câmara dos Deputados, 9 ao Senado, 6 a primeiros suplentes, 9 a segundos suplentes e 5 a vice-governadores. Elegeu o vice-governador do Piauí, 10 deputados federais e 17 estaduais, e obteve a primeira suplência no Piauí e Ceará. No total, recebeu 2,25\% dos votos válidos para deputado federal (Sorrentino; Bezerra; Carvalho, 2002/2003: 19-24).

O resultado da eleição foi interpretado pelo $\mathrm{PC}$ do $\mathrm{B}$ como um momento histórico na trajetória política brasileira, comparável a outros como a Independência, a Proclamação da República e a Revolução de 1930. A chegada de Lula ao poder também foi vista como "a vitória de uma idéia" construída pelo PC do B desde os anos 1960, consubstanciada na defesa da formação de uma frente política de luta contra a ditadura e depois contra o projeto neoliberal de Collor e Fernando Henrique Cardoso (Buonicore, 2002/2003). A respeito da atuação do novo governo, o partido indicava a necessidade de se manter uma frente política que pudesse lhe dar sustentação. Além disso, apontava que sua tática política não poderia ser radicalizada e que o papel do partido era o de ser parte integrante do governo e não uma "alternativa de esquerda". O principal desafio do governo e das forças que lhe dariam apoio seria o de retomar um novo ciclo de crescimento econômico com "bases novas e tomar iniciativas de caráter distributivo de renda" (Rabelo, 2002/2003).

$\mathrm{Na}$ formação da equipe, o PC do B ficou com o Ministério dos Esportes, ocupado por Agnelo Queiroz, e com a liderança do governo na Câmara, com Aldo Rebelo. O partido ressaltou que era a primeira vez na história que comunistas ocupavam tais cargos, o que representava o aumento do seu prestígio. Mas o significado maior "dessa participação seria a firme decisão do PC do B de tudo fazer para consolidar o governo Lula e impulsioná-lo a realizar as mudanças que o Brasil precisa". ${ }^{41}$

Passados poucos meses da nova administração, o PC do B realizou uma conferência nacional para discutir a nova conjuntura política e seu papel dentro da coligação que apoiava o governo. Na resolução final, o partido reafirmou o posicionamento que iria marcar sua atuação no período recente. De um lado, observou que Lula assumira a presidência em condições de difícil governabilidade e vulnerabilidade decorrentes do legado do governo anterior. Além disso, o período se caracterizava também por uma dualidade de forças políticas, em que se debatiam um projeto conservador, ligado ao neoliberalismo, e outro democrático e popular, representado pelo novo governo (PC do B, 2003). Este, por sua vez, 
diante das condições políticas, apresentava uma feição contraditória: "assume um caráter democrático e dá seguimento, ao mesmo tempo, à política econômica anterior" (Ibidem: 17).

Nessa situação, o papel do partido deveria ser o de apoiar o governo Lula na condução das mudanças de caráter nacional-desenvolvimentista em curso no país. $\mathrm{O}$ apoio dado ao governo assumia um caráter estratégico, uma vez que, para o PC do B, seria através dele que existiria a possibilidade mais avançada e viável no quadro de lutas da época. $O$ fracasso do governo Lula, afirmava o partido, "seria também a derrota das forças de esquerda e renovadoras e, mais ainda, a via para a volta das forças conservadoras ao centro do poder" (Ibidem: 27). Assim prosseguia o $\mathrm{PC}$ do $\mathrm{B}$, de forma a não deixar dúvida quanto ao foco de sua política diante da nova situação aberta com a vitória da Coligação Lula Presidente:

o centro de nossa tática, tendo presente o sentido estratégico já referido, é atuar pelo êxito do governo Lula na condução das mudanças que consistem no aprofundamento da democracia e na adoção de um projeto nacional de desenvolvimento, voltado para a defesa da soberania do país e o progresso social. Por isso, a ação política decorrente traduz-se em dois movimentos inseparáveis:

1) o esforço conjunto de concretizar a saída da engrenagem neoliberal para o começo do novo projeto; e

2) reunir forças populares, democráticas, patrióticas, renovadoras para o sucesso desse propósito (...) (Ibidem: 29).

As afirmações programáticas da $9^{\mathrm{a}}$ Conferência do $\mathrm{PC}$ do $\mathrm{B}$ definem com clareza a atual fase da política adotada pelo partido. Defensor entusiasta do projeto do governo, enfrenta, assim como o próprio PT, a dificuldade de lidar com as esperanças e demandas de amplos setores da população que foram secularmente marginalizados pela conservadora elite brasileira. Entretanto, diante dos problemas colocados pela governabilidade, tem entrado em contradição, ou pelo menos deixado de enfatizar claramente propostas que defendia até pouco tempo atrás, como a reforma agrária, o questionamento do pagamento da dívida externa, entre outras. Atualmente, com a crise que se abate sobre o governo, continua a defender o presidente do que chama de ataques da direita brasileira. Poucos se arriscariam, diante dos graves impasses atuais, a fazer um prognóstico sobre o futuro do PC do B e das forças de esquerda no país neste momento em que se aproxima o final do segundo governo Lula. 
1. Até pouco tempo atrás seria praticamente impossível a escrita de um artigo de história versando sobre um período recente, vivido pelo próprio autor. Felizmente, hoje, os historiadores que estudam o presente já encontram subsídios teóricos que os ajudam em seu caminho. Para o estudo da história do tempo presente, assim como de qualquer período, faz-se necessário o amparo teórico e o diálogo com o campo de estudo com o qual se está tratando. Neste caso, acredito que os aportes do Instituto de História do Tempo Presente, da França, ajudam a enfrentar as questões colocadas. O Brasil também tem produzido trabalhos na área, como atestam os trabalhos dos pesquisadores do CPDOC e de outros grupos de pesquisa em atuação no país. Ver Chauveau e Tétard (1999), Rémond (2003), Ferreira e Amado (2006) e Porto Jr. (2007).

2. Reforçar a unidade alcançada e intensificar a luta. A classe operária, maio/junho de 1984.

3. Mobilização popular e democrática para vencer as forças reacionárias. A classe operária, maio/ junho de 1984.

4. O PC do B na transição democrática. A classe operária, março/ abril de 1985.

5. Reuniu-se a Direção Nacional do PC do B: uma segura orientação para novas batalhas. A classe operária, dezembro de 1985/janeiro de 1986.

6. $\mathrm{O} \mathrm{PC}$ do $\mathrm{B}$ face ao governo e à situação do país. A classe operária, março de 1986.
7. Sobre a campanha eleitoral de 1986. A classe operária, março de 1986.

8. Fora Sarney, Diretas 88! A classe operária, novembro de 1987, p. 1; O governo naufragou. Povo exige eleições em 88. Ibidem, p. 2.

9. O povo brasileiro venceu. A classe operária, 17 a 30 de agosto de 1988, p. 3.

10. Conclamação à unidade das forças populares. A classe operária, 12 a 25 de janeiro de 1989, p. 5.

11. União da esquerda para ganhar a presidência. A classe operária, 6 a 19 de abril de 1989, p. 1.

12. A classe operária, 4 a 17 de maio de 1989; A FBP está nas ruas.

A classe operária, 8 a 31 de maio de 1989, p. 3 .

13. Suplemento Especial. A classe operária, 4 a 17 de maio de 1989.

14. Suplemento: às urnas, pela vitória do povo! A classe operária, 9 a 22 de novembro de 1989.

15. O povo venceu a $1^{\text {a }}$ batalha. A classe operária, 24 de novembro a 6 de dezembro de 1989.

16. O ano da oposição popular. A classe operária, 12 a 25/01/1990, p. 3.

17. Ibidem.

18. Ver as edições de $A$ classe operaria de 6 de julho, 3, 17 e 31 de agosto de 1992.

19. Ver $A$ classe operária, 12 de outubro de 1992, p. 9.

20. Importante discussão. $A$ classe operária, 26 de outubro a 8 de novembro de 1992, p. 6. 
21. República, sim. Parlamentarismo, sim. A classe operária, 14 de dezembro de 1992 a 17 de janeiro de 1993, p. 7.

22. União das forças progressistas na sucessão presidencial.

A classe operária, 7 a 27 de fevereiro de 1994, p. 5.

23. Neoliberalismo volta a atacar. A classe operária, 21 de junho a 4 de julho de 1993, p. 3.

24. As eleições gerais e o novo governo. Nota da Direção Nacional do PC do B. Princípios, novembro-dezembro de 1994/ janeiro de 1995, p. 9-10.

25. Ibidem.

26. O Brasil precisa de mais democracia.

Nota da Comissão Política do PC

do B. A classe operária, agosto de 1995 , p. 3.

27. Candidato único da oposição para

98. A classe operária, 17 de junho de 1997, p. 2; Oposição discute plataforma comum. A classe operária, 11 de setembro de 1997, p. 2.

28. Derrotar o continuísmo de FHC.

Nota do Comitê Central do PC do B. A classe operária, $1^{\circ}$ de abril de 1998 , p. 5.

29. Esquerda unida lança a chapa Lula-Brizola. A classe operária, 14 de maio de 1998, p. 1.

30. A esquerda realizou uma campanha histórica. A classe operária, 15 de outubro de 1998, p. 3.

31. Aumentam os votos na oposição. Ibidem.
32. Os comunistas e o resultado das eleições. Ibidem, p. 4.

33. Oposição firme e decidida a FHC. A classe operária, 20 de janeiro de 1999, p. 4.

34. Preparar o partido para as eleições de 2000. A classe operária, 21 de julho de 1999, p. 3.

35. Quadro de coligações do PC do B para prefeito(a) e vereador(a) nas capitais dos estados. A classe operária, 13 de julho de 2000 , p. 4.

36. Maré vermelha em Pernambuco. A classe operária, 3 de novembro de 2000 , p. 1; A primeira prefeita comunista. Ibidem, p. 7.

37. Ampliar as forças para garantir a vitória oposicionista em 2002. Ibidem, p. 1; Consagração da esquerda em SP. Ibidem, p. 7.

38. Lula propõe aliança ao PC do B. A classe operária, 10 de maio de 2002, p. 2.

39. Comissão Política do PC do B. Idéias fundamentais à elaboração do programa para um novo rumo para o Brasil. Princípios, maio-junho-julho de 2002, p. A5.

40. Ibidem. Grifos no original.

41. Participação dos comunistas fortalecerá o governo da mudança. A classe operária, 24 de dezembro de 2002, p. 1. 


\section{Referências bibliográficas}

AMAZONAS, J. 1985. A atualidade da Assembléia Constituinte. Princípios, São Paulo, n ${ }^{\circ} 10$.

ARANTES, A. 1996/1997. Reeleição e reforma antidemocrática do Estado. Princípios, São Paulo, $n^{\circ} 43$.

BUONICORE, A. C. 2002/2003. A vitória de uma idéia. Princípios, São Paulo, $\mathrm{n}^{\circ} 67$.

CARVALHO, J. R. 1988a. Progressistas x direita. A classe operária, São Paulo, $\mathrm{n}^{\circ} 1$.

1988b. PC do B vence com destaque. A classe operária, São Paulo, $\mathrm{n}^{\circ} 8$.

CHAUVEAU, A. \& TÉTARD, P. (orgs.). 1999. Questões para a história do presente. Bauru: Edusc.

DELGADO, L. de A. N. 2007.

Diretas-já: vozes da cidade. In: REIS FILHO, D. A. \& FERREIRA, J. As esquerdas no Brasil, vol. 3. Rio de Janeiro: Civilização Brasileira.

FERREIRA, M. de M. \& AMADO, J. (orgs.). 2006. Usos $\mathcal{E}$ abusos da história oral. $8^{\mathrm{a}}$ ed. Rio de Janeiro: FGV.

PC do B. 1989. A política revolucionária do $P C$ do B. Informes ao $7^{\circ}$ Congresso realizado em maio de 1988. $2^{\mathrm{a}}$ ed. São Paulo: Anita Garibaldi.

1992. O socialismo vive. Documentos e resoluções do $8^{\circ}$ Congresso do Partido Comunista do Brasil (PC do B). $2^{\mathrm{a}}$ ed. São Paulo: Anita Garibaldi.

- 2003. $9^{a}$ Conferência Nacional. Resolução Política. São Paulo: Anita Garibaldi.

PILAGALLO, Oscar. 2006. A história do Brasil no século 20 (1980-2000).

São Paulo: Publifolha
PORTO Jr., Gilson (org.). 2007. História do tempo presente. Bauru: Edusc.

RABELO, R. 1995. A natureza da submissão. Princípios, São Paulo, $\mathrm{n}^{\circ} 36$.

1998. Um programa para um Brasil soberano e democrático. Princípios, São Paulo, $\mathrm{n}^{\circ} 48$.

2000. Ampliar a vitória oposicionista no segundo turno. A classe operária, São Paulo, $\mathrm{n}^{\circ} 193$.

2000/2001. O novo quadro político brasileiro. Princípios, São Paulo, $n^{\circ} 59$.

. 2001a. Pontos fundamentais do programa de reconstrução nacional. Princípios, São Paulo, n ${ }^{\circ} 62$.

. 2001b. O caminho da resistência ao neoliberalismo. Princípios, São Paulo, $\mathrm{n}^{\circ} 61$.

2001/2002. O Brasil precisa de um ciclo de desenvolvimento e progresso social. Princípios, São Paulo, n ${ }^{\circ} 63$.

2002/2003. Desafios para um novo Brasil sob o governo Lula. Princípios, São Paulo, n 67.

REBELO, A. 1988. Territórios que não se confundem. A classe operária, São Paulo, $\mathrm{n}^{\circ} 1$.

1989. No olho do furacão. São Paulo: Alfa-Omega.

RÉMOND, R. 2003. Por uma história política. 2a ed. Rio de Janeiro: FGV.

RODRIGUES, A. T. 2003. Diretas já! O grito preso na garganta. São Paulo: Fundação Perseu Abramo.

RUY, J. C. 1994. As diferenças entre os programas de Lula e de Fernando 
Henrique. Princípios, São Paulo, $\mathrm{n}^{\circ} 34$.

1998. O velho conflito entre a modernidade e o atraso. Princípios, São Paulo, $\mathrm{n}^{\circ} 50$.

SALES, J. R. 2007a. A luta armada contra a ditadura militar. A esquerda brasileira e a influência da revolução cubana. São Paulo: Perseu Abramo.

. 2007b. Entre o fechamento e a abertura: a trajetória do PC do B da guerrilha do Araguaia à Nova República (1974-1985). História, São Paulo, vol. 26, $\mathrm{n}^{\circ} 2$. . 2007c. Partido Comunista do Brasil (PC do B): definições ideológicas e trajetória política. In: REIS FILHO, D. A. \& RIDENTI, M. (orgs.). História do marxismo no Brasil, vol. 7. Campinas: Editora da Unicamp.

SILVA, A. O. da. 2004. O PC do B diante da conjuntura política nacional. Revista Espaço Acadêmico, Maringá, $\mathrm{n}^{\circ} 74$ (Acesso em 23/2/2008: www.espacoacademico. com.br)

SORRENTINO, W., BEZERRA, A. \& CARVALHO, L. M. G. 2002/2003. O PC do B cresceu nas eleições 2002. Princípios, São Paulo, $\mathrm{n}^{\circ} 67$.

\section{Resumo}

O artigo analisa a história do PC do B desde a Nova República até a chegada ao governo federal juntamente com a coligação que apoiou o candidato Luiz Inácio Lula da Silva. Nesse percurso, destacamos a participação do partido nos pleitos eleitorais, que são tomados aqui como momentos importantes para a compreensão das mudanças das propostas partidárias e da sua inserção na política brasileira

Palavras-chave: Partido Comunista do Brasil (PC do B); eleições; institucionalização; governo Lula
Abstract
The article analyses PC do B's history from the New Republic to its current participation in the federal government as a member of the coalition that supported Luiz Inácio Lula da Silva. Within this course, we highlight the party's participation in elections, which are here considered key-moments to understand the changes in the party's proposals, as well as its insertion into Brazilian politics.
Key-words: Communist Party of Brazil (PC do B); elections; institutionalization; Lula Government 


\section{Résumé}

Cet article analyse l'histoire du PC do B depuis la Nouvelle République jusqu'à son arrivée au gouvernement fédéral comme membre de la coalition qui a soutenu la candidature de Luiz Inácio Lula da Silva. Dans ce parcours, nous mettons en relief la participation du parti aux élections, considérées ici comme des moments-clés pour comprendre les changements des propositions partidaires et son insertion dans la politique brésilienne.

Mots-clés: Parti Communiste du Brésil (PC do B); élections; institutionnalisation; Gouvernement Lula 